IZA DP No. 7679

Laterborns Don't Give Up:

The Effects of Birth Order on Earnings in Europe

Marco Bertoni

Giorgio Brunello

October 2013 


\title{
Laterborns Don't Give Up: The Effects of Birth Order on Earnings in Europe
}

\author{
Marco Bertoni \\ University of Padova \\ and CEP-LSE
}

\author{
Giorgio Brunello \\ University of Padova, \\ LUMS and IZA
}

\section{Discussion Paper No. 7679 \\ October 2013}

\author{
IZA \\ P.O. Box 7240 \\ 53072 Bonn \\ Germany \\ Phone: +49-228-3894-0 \\ Fax: +49-228-3894-180 \\ E-mail: iza@iza.org
}

\begin{abstract}
Any opinions expressed here are those of the author(s) and not those of IZA. Research published in this series may include views on policy, but the institute itself takes no institutional policy positions. The IZA research network is committed to the IZA Guiding Principles of Research Integrity.

The Institute for the Study of Labor (IZA) in Bonn is a local and virtual international research center and a place of communication between science, politics and business. IZA is an independent nonprofit organization supported by Deutsche Post Foundation. The center is associated with the University of Bonn and offers a stimulating research environment through its international network, workshops and conferences, data service, project support, research visits and doctoral program. IZA engages in (i) original and internationally competitive research in all fields of labor economics, (ii) development of policy concepts, and (iii) dissemination of research results and concepts to the interested public.
\end{abstract}

IZA Discussion Papers often represent preliminary work and are circulated to encourage discussion. Citation of such a paper should account for its provisional character. A revised version may be available directly from the author. 


\section{ABSTRACT \\ Laterborns Don't Give Up: The Effects of Birth Order on Earnings in Europe ${ }^{1}$}

While it is well known that birth order affects educational attainment, less is known about its effects on earnings. Using data from eleven European countries for males born between 1935 and 1956, we show that firstborns enjoy on average a 13.7 percent premium over laterborns in their wage at labour market entry. However, this advantage is short lived, and disappears by age 30, between 10 and 15 years after labour market entry. While firstborns start with a better match, partly because of their higher education, laterborns quickly catch up by switching earlier and more frequently to better paying jobs. We argue that a key factor driving our findings is that laterborns are more likely to engage in risky behaviours.

JEL Classification: D13, J12, J24

Keywords: birth order, earnings, risk aversion, Europe

Corresponding author:

Giorgio Brunello

Department of Economics and Management "M. Fanno"

University of Padova

Via del Santo, 33

35123 Padova

Italy

E-mail: giorgio.brunello@unipd.it

\footnotetext{
${ }^{1}$ We thank Hessel Oosterbeek, Erik Plug, Olmo Silva, Guglielmo Weber, Christoph Weiss and the audience at a workshop in Reus for comments and suggestions. This paper uses data from SHARELIFE release 1, as of November 24th 2010 and SHARE release 2.5.0, as of May 24th 2011. The SHARE data collection has been primarily funded by the European Commission through the 5th frame work programme (project QLK6-CT-2001-00360 in the thematic programme Quality of Life), through the 6th framework programme (projects SHARE-I3, RII-CT-2006 062193, COMPARE, CIT5CT-2005-028857, and SHARELIFE, CIT4-CT-2006-028812) and through the 7th frame work programme (SHARE-PREP, 211909 and SHARE-LEAP, 227822).
} 


\section{Introduction}

Does birth order affect wages? According to Ruth Mantell of the Wall Street Journal, 2011, the answer is clearly positive. She reports that firstborn kids are “...the most likely to earn six figures and hold up a top executive position among workers with siblings...”. She also quotes economist Sandra Black as saying that “... birth order affects educational attainment, which then affects earnings [...]. Laterborns earn less than firstborns, and a substantial part of this difference is due to the fact that laterborns get fewer years of education."

While there is substantial empirical research investigating the effects of birth order on educational attainment, less has been done to explore the effects on earnings. One reason could be the scarcity of datasets containing information both on earnings and on birth order. Another reason, we suspect, is that the research question is viewed as not particularly interesting. If one believes, as many economists do, that earnings are a function of human capital, evidence that firstborns have better education implies that they also have higher earnings.

Yet - with a single important exception ${ }^{2}$ - the few studies that have addressed this issue have found that the effects of birth order on earnings are rather negligible, in spite of the significant effects on educational attainment. For example, in their study of Swedish data, Björklund and Jäntti, 2012, find that firstborns attain on average 0.2 more years of education than laterborns, but only a $0.25 \%$ premium on earnings between ages $31-40$. Given that returns to education in Sweden range between 3.5 and 5.5 percent (see Harmon, Oosterbeek and Walker, 2003), the estimated premium is much lower than the expected 0.7-1.1 percent. These studies also focus on earnings at a given point in a working lifetime, typically before age forty, or on average earnings over a short period of the working life cycle, and are therefore silent on whether birth order has a temporary or a permanent impact on individual earnings.

In this paper, we contribute to this small literature by studying the effects of birth order on earnings over the life cycle in a sample of 4,280 individuals born between 1935 and 1956 and

\footnotetext{
${ }^{2}$ Kantarevic and Mechoulan, 2005, find that order of birth has a significant effect on hourly earnings in a relatively small sample of US workers.
} 
residing in eleven European countries (Austria, Belgium, the Czech Republic, Denmark, France, Germany, Italy, the Netherlands, Spain, Sweden and Switzerland). We consider several measures of real annual earnings: the entry wage - defined as the initial wage in the first job - wages at age 30, 40 and 50 , and the current or last wage, defined either as the wage in the job currently held if still active at age 50 plus or as the wage in the last job before retiring. We also add a measure of lifetime earnings, or the discounted value of the stream of earnings from age ten to retirement. By looking at earnings at different points in the life cycle, and at lifetime earnings, we can tell whether the estimated birth order effects on earnings are temporary or permanent.

We show that the advantage enjoyed by firstborns over laterborns is short lived: they earn on average a $13.7 \%$ premium in their entry wage, but this advantage is completely gone by age 30 . We also find that being a firstborn has no statistically significant effect on earnings at age 50 and on the current wage. Since the initial wage gains are quickly lost, and laterborns start working earlier than firstborns, it is not surprising that being a firstborn has no statistically significant effect on lifetime earnings.

The temporary advantage enjoyed by firstborns implies that birth order has a positive effect on earnings growth, measured as wages at age $t$ minus the entry wage. Importantly, we find that this effect remains even after controlling for educational attainment. This suggests that differences in education between firstborns and laterborns are not sufficient to explain the observed differences in wages over the lifecycle. We also find that education negatively affects earnings growth, a result consistent both with the learning model by Altonji and Pierret, 2001, and with the human capital model, provided that education and experience are substitutes in the production of skills.

Temporary birth order effects are closely associated to differences in job-to-job mobility after labour market entry. On the one hand, firstborns find better initial matches - not only they earn more, but they are also more likely than laterborns to be in white collar and in public sector jobs and stay on their initial jobs longer. On the other hand, laterborns start with poorer matches but change jobs swiftly, and by virtue of job mobility quickly catch up with firstborns. To illustrate the effects of mobility, we compare expected log wages at age 30 for firstborns and laterborns and find 
that they are quite similar (a $0.7 \%$ advantage for laterborns). These wages can be expressed as the weighted average of log wages for those still in the first job at age 30 and log wages for those in other jobs, using as weights the probability of being in the first job at age 30 . While firstborns who are still in their first job at age 30 retain a 5\% advantage on earnings over laterborns in their first job at 30 , this advantage is more than compensated by the fact that, at that age, laterborns have a higher probability of being already in their second or third job, that pay higher earnings than the first job. A similar pattern holds at age 40 as well.

Drawing on a vast literature in psychology (see for instance Sulloway, 2007) and using our own evidence in support, we argue that firstborns differ from laterborns both because they have higher education and because they are less likely to engage in risky behaviours (see Wang et al., 2009). On the one hand, better education explains why firstborns start with a better match. On the other hand, the higher propensity to take risks explains why laterborns incur in higher turnover (see Allen et al, 2005) and enjoy higher wage growth than firstborns (see Shaw, 1996).

The paper is organized as follows: we briefly review the relevant literature in Section 1, introduce the data in Section 2 and discuss the empirical methodology in Section 3. Our results are reported in Section 4. We discuss our findings in Section 5 and present a few extensions in Section 6. Conclusions follow.

\section{Review of the Literature}

The effects of birth order on educational attainment have been widely studied. In a recent influential contribution, Black, Devereux and Salvanes, 2005, (BDS from now on) use Norwegian registry data and find that birth order has a significant and large negative effect on children's education, even after controlling for family size. In particular, they estimate that being a second child reduces educational attainment with respect to being a firstborn by close to 0.3 years of schooling. Negative effects have been found also in recent research by Bagger et al., 2013, for Denmark, Björklund and Jantti, 2012, for Sweden, and De Haan, 2010, and Kantarevic and Mechoulan, 2005, for the US. 
Less has been done to investigate the effects of birth order on earnings. Most of the existing studies are based on US data and consider earnings relatively early in an individual's career (before age 40). While results are sensitive to the inclusion of covariates, the broad assessment is that the estimated effects tend to be small or negligible. Behrman and Taubman, 1986, use US data for young adults and show that, after adjusting for age or work experience, there are differences by birth order in both schooling and log earnings. The effects on earnings, however, become statistically insignificant when they include controls for observed childhood family background characteristics.

Olneck and Bills, 1979, examine the effect of birth order and family size on childhood test scores and adult levels of education, occupation, and wages, finding a negligible influence of birth order on all measures of achievement. Kessler, 1991, uses data from the US National Longitudinal Survey of Youth to examine the effect of birth order and family size on individual behaviour over the course of teenage and early adult lives. He finds that neither birth order nor childhood family size significantly influences the level or growth rate of wages for individuals aged 14-22, 18-26 and 22-30.

Björklund and Jäntti, 2012, use Swedish registry data and report that the firstborn child attains 0.2 years of additional education and earns around $0.25 \%$ higher long-run earnings (earnings are measured at ages 31-40) than other siblings. After examining other outcomes, they conclude that birth order is not a major source of the family impact on economic outcomes and thus not a major source of inequality of opportunity. ${ }^{3}$

To our knowledge, the work by Kantarevic and Mechoulan, 2005, stands out as the only paper to date that finds significant effects of birth order on (hourly) earnings. The authors use data from the Childbirth and Adoption History File (CAHF), a special supplemental file of the US PSID (Panel Study on Income Dynamics) ${ }^{4}$ and find that, when the age of the mother at birth is omitted from the vector of covariates, birth order has no statistically significant effect on earnings. When age

\footnotetext{
${ }^{3}$ Yet, in a recent contribution, De Haan, Plug and Romero, 2012, find that birth order affects early outcomes in Ecuador.

${ }^{4}$ Their sample is rather small (3000 observations) and pools together males and females.
} 
is included, they report that the hourly earnings of firstborns are $6.3 \%$ higher than those of laterborns. $^{5}$

\section{The data}

In this paper, we use the Survey of Health, Ageing and Retirement in Europe (SHARE), a multidisciplinary and cross-national European data set containing current and retrospective information on labour market activity, retirement, health and socioeconomic status of more than 25,000 individuals aged 50 or older. We draw our data from the first three waves of the survey, and in particular the third wave, SHARELIFE, which contains detailed retrospective data on life and labour market histories. We focus on males because of the problems associated with female labour force participation and exclude the self-employed and people aged 50+ who have worked less than 5 years. ${ }^{6}$ In SHARELIFE, survey participants are asked to report the amount they were paid monthly after taxes each time they started an employment spell. They are also asked the monthly net wage in their current job (if they are still working) and the monthly net wage at the end of the main job in their career (if they have already retired). For wages and other benefits to be comparable across time and country, we follow Brunello, Weber and Weiss, 2012, and transform them into 2006 Euro using PPP exchange rates and CPI indices.

We use these rich data to construct for each individual several measures of real annual earnings, that span his working life from the first to the current or last job. We start with the entry wage $W_{1}$, defined as the initial wage in the first job. Since information on this wage is missing for about 25 percent of the individuals in our final sample, we use predictive mean matching to impute missing data and obtain $\overline{W_{1}} \cdot$. We also compute the initial wage in the second and third job, the current or last wage, the wages at age 30, 40 and 50 and lifetime earnings.

\footnotetext{
${ }^{5}$ The statistical significance of this effect falls from 5 to $10 \%$ when father's education and the age of the father at childbirth are added to the covariates.

${ }^{6}$ Murphy and Welch, 1990, also exclude the self-employed in their analysis of age-earnings profiles.

${ }^{7}$ As shown in Section 4, our results do not depend on imputation. Predictive mean matching replaces a missing value with the observed value for which the predicted value is the closest to that of the missing value. See Weiss, 2012, for details. The percentage of missing values is very similar among firstborns $(23.2 \%)$ and laterborns $(24.3 \%)$.
} 
We define lifetime earnings (or permanent income) as the income flowing from the asset value of working at age ten. The construction of this variable and of wages at different ages is described in detail both in Appendix A of Brunello, Weber and Weiss, 2012, and in Weiss, 2012. In short, for those who have had only one job in their working life (more than 20 percent of the sample), we interpolate between the first wage and the last (or current) wage. For those who have had more than one job, we observe the first wage in each job as well as the current or last wage. For this second group, we regress current wages on labour market experience, a rich set of controls, which include education, occupation, sector of activity, cohort and country effects and economic conditions at age ten, and the interactions of these controls with experience. We then use the estimated coefficients and the first wage in each job to generate both the final wage in the job and within-job earnings growth. ${ }^{8}$ With this information in hand, we compute annual wages at age 30, 40 and 50 and the discounted value of earnings at age ten, using a 2 percent discount rate. ${ }^{9}$

Our dataset has the advantage that it covers eleven European countries, and the potential drawback that it uses long recall data. These data are subject to measurement error, possibly not of the classical type. However, as discussed in Brunello, Weber and Weiss, 2012, validation studies have found that recall bias is not severe in SHARELIFE data, arguably because of the state-of-the-art elicitation methods used: respondents are helped to locate events along the time line, starting from domains that are more easily remembered, and then asked progressively more details about them.

Our final sample consists of 4,280 individuals born between 1935 and 1956 and residing in Austria, Belgium, the Czech Republic, Denmark, France, Germany, Italy, the Netherlands, Spain, Sweden and Switzerland. ${ }^{10}$ While waves 1 and 2 of the survey have information on order of birth ("Were you the oldest child, the youngest child, or somewhere in-between?"), wave 3 has data on individual and household conditions at age ten. We rely on answers to the question "Including

\footnotetext{
${ }^{8}$ Brunello, Weber and Weiss, 2012, show that estimates are broadly unaffected when they replace labour market experience with age and exclude education in the wage regressions used to generate both the end wage in each job and within-job earnings growth for individuals who have had more than one job.

${ }^{9}$ We are very grateful to Christoph Weiss for providing the codes required to compute earnings profiles and lifetime earnings from the third wave of the survey SHARE.

${ }^{10}$ By selecting only individuals born from 1935 onwards, we reduce the role of survivorship bias (see Modin, 2002) and recall bias for older workers, the weight of imputation, and also make sure that no individual in our sample entered the labour market before the second World War.
} 
yourself, how many people lived in your household at this accommodation when you were ten?" to measure gross family size, which includes both siblings and other members. ${ }^{11}$ We also use the answers to the question "Who lived in the household when ten" to estimate net family size, or the number of siblings, by subtracting other members (parents, grandparents and other relatives) from gross family size. In our data, the average household size at age ten is 5.44 members, and the average number of siblings is $3.34 .^{12}$ As shown in Table 1 , the distribution of siblings varies with whether the interviewed individual is the oldest child or not, mainly because 24 percent of oldest children are only children. Compared with the distribution of siblings in the Norwegian sample used by BDS, our sample comprises households with a higher number of siblings, which reflects both the different sample period - the individuals are born between 1935 and 1956 in our sample and between 1912 and 1984 in BDS's sample - and the fact that our sample includes also Southern European countries, where the number of siblings is typically higher (2.90 in Sweden and 3.88 in Spain).

The third wave of SHARE also contains a wealth of data on household and individual conditions at age ten. We define the vector $X$ as comprising the following covariates: whether the household was located in a rural area or a village, dummies for the profession of the main breadwinner, a dummy for the presence of hunger episodes before age 15, a dummy indicating whether parents smoked, drank heavily o had mental health problems during childhood, a dummy if one parent died before age 35, and dummies for the presence of parents, grandparents or foster parents in the household. $^{13}$

Unfortunately, our information on the age of the parent at birth is available only for those parents who were still alive at the time of the interview. We check whether omitting this critical piece of information significantly affects our estimates by running our regressions with and without the age of the mother at birth in the sub-sample where this measure is available. As reported below,

\footnotetext{
${ }_{11}$ Needless to say, household size at age ten is less correlated with order of birth than household size at birth. For the small minority of individuals for which this information was not available - around 2 percent of our sample - we reconstruct sibship size using information on the number of siblings alive at the time of the first SHARE interview.

${ }^{12}$ We recode the number of siblings so that the top category is 10 or more.

${ }^{13}$ We exclude information such as the number of books in the household and housing facilities at age ten because they could be affected by birth order, as suggested by De Haan, Plug and Romero, 2012.
} 
our evidence suggests that omitting maternal age at birth does not affect our estimates in a qualitative way.

Table 2 shows the summary statistics of the main variables used in this study, separately by order of birth (firstborns and laterborns). The statistics for the full sample are reported in Table A1 in the Appendix. These tables suggest that firstborns are on average better educated than laterborns (12.59 versus 11.49 years of schooling), start working later (at age 19.6 versus 18.6) and have a substantially higher entry wage (11,786 real euro versus 10,577 , a $11.4 \%$ premium). This "premium" declines with the second and third job and with age and is close to $3.3 \%$ in the current or last wage $(23,546$ versus 22,787). Firstborns have fewer siblings (1.51 versus 2.91) than laterborns. Furthermore, the households where firstborns lived at age ten were more likely to be located in urban areas and to have a white collar breadwinner, indicating that household wealth was also higher.

\section{Empirical Methodology}

We estimate the following linear regression model:

$$
\ln w_{i t}=\alpha+\beta O_{i}+\gamma F_{j}+\delta X_{i}+\mu_{s}+\mu_{c}+\varepsilon_{i t}
$$

where the subscripts $i, j$ and $t$ are for individuals, households and time, $w$ is annual real earnings, $O$ is a dummy equal to 1 if the individual is firstborn and to 0 otherwise ${ }^{14}, F$ is the number of siblings in the household when the individual was ten, the vector $X$ is described in the previous section, $\mu_{c}$ and $\mu_{s}$ are cohort and country fixed effects and $\varepsilon_{i t}$ is an error term, which can be decomposed as $\varepsilon_{i t}=\lambda_{j}+\eta_{i}+v_{i t}$, where $\lambda_{j}$ and $\eta_{i}$ are family and individual fixed effects and $v$ is random noise. Since we are interested in the effects of being firstborn on earnings at different points of the life cycle, we use as dependent variable (in logs): the entry wage, the initial wage in the second and third job, the wage at ages 30, 40 and 50, the current or last wage and lifetime earnings.

\footnotetext{
${ }^{14}$ As in BDS, we treat children without siblings as firstborns. As discussed later in the paper, sensitivity analysis which excludes firstborns yields very similar results.
} 
As discussed by Bagger et al, 2013, family size can be viewed as the outcome of inter-temporal utility maximization by altruistic parents, and the family fixed effect $\lambda_{j}$ as a function of parental spending and preferences, at least partly unobserved by the analyst. Parental choice implies that family size is a function of $\lambda_{j}$. Since parents typically choose size and individual investment in human capital, which affects earnings, the family fixed effect affects individual outcomes directly. Birth order depends directly on family size and only indirectly on the family fixed effect.

The identification of birth order effects in Eq. (1) is complicated by the fact that, while the order of birth may well be considered as good as randomly assigned within a given family, the question is less clear-cut when variation between families is also used, as we do. As shown in Table 2, firstborn individuals belong more frequently to smaller families, and smaller families are not only typically better off, but may also devote more time and economic resources to each child (the quality-quantity trade-off discussed by Becker and Lewis, 1973). Since family size depends both on observable and on unobservable parental traits that may also be related to earnings capacity, the omission of some of these traits in Eq.(1) biases the estimated coefficient of family size, and contaminates the estimates of birth order effects.

BDS address this problem by using two approaches: the first approach relies on selection on observables and consists of including a rich set of covariates describing economic and social conditions of families, in the hope that this set mops up the family fixed effect. In the second approach, they use family fixed effects, thereby focusing on within-family variation in educational outcomes. We capture some household traits by conditioning our estimates on the covariates included in vector $X$. When these effects are netted out and we estimate (1) by ordinary least squares, the bias in the estimated coefficient of birth order is

$$
\beta_{O L S}=\beta+\frac{\operatorname{Cov}\left(O_{i}, F_{j}\right)}{\operatorname{Var}\left(O_{i}\right)}\left(\gamma-\gamma_{O L S}\right)+\frac{\operatorname{Cov}\left(O_{i}, \lambda_{j}\right)}{\operatorname{Var}\left(O_{i}\right)}+\frac{\operatorname{Cov}\left(O_{i}, \eta_{i}\right)}{\operatorname{Var}\left(O_{i}\right)}
$$


Since birth order depends on $\lambda_{j}$ only indirectly, $\operatorname{Cov}\left(O_{i}, \lambda_{j}\right)=0$. Furthermore, $\operatorname{Cov}\left(O_{i}, \eta_{i}\right)=0$ if there are no genes for being firstborn. ${ }^{15}$ Therefore, the bias in (2) is driven by the negative correlation between order of birth and family size $\operatorname{Cov}\left(O_{i}, F_{j}\right)$ and by the OLS bias in estimated family size effects $\left(\gamma_{O L S}-\gamma\right) \neq 0$. By removing this bias, family fixed effects guarantee that the estimate of birth order effects is consistent. Alternatively, one can set to zero the covariance between order of birth and family size by estimating separate regressions by family size, as done for instance by BDS.

Since in our data we do not observe multiple members within the same original family, we cannot estimate (1) using family fixed effects. We therefore estimate Eq. (1) by family size and show that the qualitative results based on these estimates are broadly unaffected when we pool different family sizes. This suggests that the bias induced by pooling has relatively small effects on the coefficient of interest, which measures the effects of birth order on labour market outcomes. Reassuringly for our estimation strategy, BDS find that birth order effects on educational attainment are rather homogeneous across families of different size, and that their estimates do not vary much when family fixed effects are added to tease out unobservable family characteristics.

Notice that empirical strategies that rely on family fixed effects are not entirely free of problems. To see why, consider that within a given family firstborn and laterborn children usually belong to different birth cohorts, and therefore tend to face different macroeconomic and labour market conditions at several key moments of their lives. ${ }^{16}$ This may confound the effect of birth order on earnings.

Since we have measures of real annual earnings at different points of an individual working life as well as a measure of lifetime earnings, we can study how the effects of birth order on earnings vary

15 BDS, 2005, argue that “...in general, there are no genes for being a firstborn or a laterborn so it is unlikely that the birth order effects we find have genetic or biological causes...", p.20. De Haan, Plug and Rosero, 2012, have recently questioned this assumption on the ground that that laterborns may face higher prenatal environmental risks because of increased levels of maternal antibody, that may attack the development of the brain in utero.

${ }^{16}$ For instance, Angelini and Mierau, 2012, find negative effects of bad macroeconomic conditions at birth on childhood health. Lindeboom et al., 2006, find negative mortality effects of a recession at birth. Giuliano and Spilimbergo, 2009, estimate negative effects of recessions during early adulthood on self-confidence, locus of control and other beliefs. Most relevant for our purposes, Oreopoulos et al., 2010, find negative effects of graduating during a recession on employment and earnings - especially in the short run. 
over the life cycle. To illustrate, suppose that firstborns have a higher initial wage in their first job than laterborns, and assume that we can observe the wage of both groups at age 50 . We can then estimate

$$
\ln W_{i 50}-\ln W_{i F}=\left(\alpha_{50}-\alpha_{F}\right)+\left(\beta_{50}-\beta_{F}\right) O_{i}+\left(\gamma_{50}-\gamma_{F}\right) F_{j}+\left(\delta_{50}-\delta_{F}\right) X_{i}+\phi_{S}+\phi_{C}+\left(v_{i 50}-v_{i F}\right)
$$

where the subscripts 50 and $F$ are for the late and the entry wage, and the parameters $\phi$ are country and cohort effects. This approach has the advantage that it differences out both family and individual fixed effects. Assuming that $\beta_{F}>0$, by estimating (3) we can evaluate whether the positive effect of birth order on earnings persists $\left(\beta_{50}-\beta_{F}=0\right)$, increases $\left(\beta_{50}-\beta_{F}>0\right)$ or declines $\left(\beta_{50}-\beta_{F}<0\right)$ over time.

\section{Main results}

We introduce the presentation of our estimates by showing in Table 3 the estimated effect of the dummy "oldest child" on educational attainment, both by family size (two, three and four siblings) and by pooling all sizes. We find a positive and statistically significant effect, that ranges between 0.645 and 0.749 years of education, similar to the average effect estimated by BDS for Norway $(0.656)^{17}$ but much higher than the effect estimated by Björklund and Jäntti for Sweden (0.248).

Our key results are presented in Table 4, where we show estimated birth order effects both on the entry and on the current or last wage, separately by number of siblings ${ }^{18}(2,3$ or 4 siblings) and by pooling together all different family sizes, after controlling for sibship size. The table is organized in eight columns, four for each definition of earnings. We find that the dummy "oldest child" has a positive, sizeable and statistically significant effect on the entry wage. Depending on the number of

\footnotetext{
17 This effect is computed as the arithmetic mean of the effect of being the second to the tenth child. See Table 8 , column 1 of BDS.

18 Similarly to Price, 2008, we stop at 4 siblings because sample size would fall drastically if we were to consider households with a higher number of siblings.
} 
siblings, our estimates suggest that firstborns earn at labour market entry approximately 13.5 to $18.6 \%$ more than laterborns, a substantial amount. Yet, this gain is gone by age 50 or later.

The table also shows that our qualitative results are not affected if we pool families with different number of siblings. For instance, we estimate that firstborns enjoy a 13.7\% premium with respect to laterborns in their entry wage and no premium at all in their current wage. Because of this, we will focus the presentation of our results in the rest of this section on the sample that pools all family sizes. ${ }^{19}$ In Table 5, we look at earnings measured at different points of the lifecycle (age 30, 40 and 50), as well as at lifetime earnings, and confirm that order of birth matters only at labour market entry.

Since some of the data have been imputed, one may worry that our findings are driven by imputation. Table 6 compares estimated birth order effects on entry and current earnings in the samples with and without imputation, and shows that these effects are quite similar. Without imputed data, the marginal effect on the entry wage is slightly smaller at $12.9 \%$ rather than at $13.7 \%$. However, the two estimates are not statistically different.

An additional source of concern is that the estimates in Table 4 do not control for the age of the mother at birth. This can affect our estimates, as parents of firstborns are likely to be younger than parents of laterborns. Unfortunately, our data include information on the age of parents at birth only for the interviewed individuals whose parents were still alive at the time of the survey. Given that the survey focuses on individuals aged $50+$, this is only a minority of the original sample. Nonetheless, for this smaller sample we can compare estimates with and without controlling for the age of the mother at birth. As reported in Table 7, including the age of the mother at birth as additional covariate in the regressions has virtually no effect on our estimates.

Our results suggest that the effect of being firstborn on earnings is temporary and dies out as individuals increase their experience in the labour market. To confirm this, Table 8 presents the estimated effects of birth order on earnings growth over the life cycle, measured alternatively as the difference between earnings at 30,40, 50 or current earnings and the entry wage. By differencing

\footnotetext{
${ }^{19}$ Detailed results by family size are available from the authors upon request.
} 
individual wages over the life cycle, we are able to purge our estimates from fixed family and individual effects. In all cases, the estimated coefficient associated to being firstborn is negative, statistically significant and between -13.5 and $-16.2 \%$, confirming that firstborns may have an early advantage, but that laterborns quickly catch up.

We investigate whether the birth order effect disappears when we control for differences in educational attainment by adding years of schooling as an additional covariate in the earnings growth regressions, where the fixed individual and family effects which correlate with education have been removed. Table 9 shows that education attracts a negative and statistically significant coefficient, and that the effect of birth order remains even after conditioning on education, although with a lower absolute value. This finding suggests that education is not the only "mediator" of the effects of birth order on earnings.

Finally, we consider the effects of birth order on the probability of not having a job at different ages, starting with age 20 . We estimate linear probability models and report in Table A2 that firstborns have higher probabilities of being without a job early on in their career (at age 20 and 25) and are as likely as laterborns to be employed at later ages. Clearly, this effect reflects the fact that firstborns are more likely to stay in school longer.

\section{Discussion}

Our key findings can be summarized as follows: a) birth order effects on earnings are temporary and decline with labour market experience; b) these effects cannot be fully explained by the higher educational attainment of firstborns; c) higher education reduces earnings growth. The last result is consistent both with the learning model of Altonji and Pierret, 2001, and with the human capital model if early and later learning episodes are substitutes rather than complements. ${ }^{20}$ These models, however, need to be adequately adapted to encompass also findings a) and b).

\footnotetext{
${ }^{20}$ In their classical paper on employer learning and wage dynamics, Altonji and Pierret, 2001, have shown that, when employers observe schooling but have only repeated noisy observations on cognitive skills, which affect productivity and are positively correlated with schooling, the effect of education on earnings declines with labour market experience, in line with our results. The human capital model is also consistent with our results if the earnings capacity invested in human capital during work declines with education. Mincer reports that returns to education decline with experience
} 
For this purpose, it is useful to use the retrospective information on working histories available in our data and briefly describe the labour market careers of firstborns and laterborns. By so doing, we highlight the importance of labour mobility in the process of catching up of the latter with the former. Table 10 shows that firstborns are less mobile: they are 4.1 percentage points less likely than laterborns to have more than a single job in their careers, and more likely to be employed in their first job as white collar workers or as public sector employees. ${ }^{21}$ These jobs are typically more stable than private sector jobs (see Clark and Postel-Vinay, 2009), and in some countries they are also associated to milder age earnings profiles. ${ }^{22}$

Mobility allows laterborns to catch up with firstborns. We document this by focusing on two snapshots in the working life of the individuals in our sample: age 30 and 40. For each selected age, we compare two groups, those who were still in their first job by that age (stayers), and those who had changed job (movers). As shown in Table 11, the probability of being a stayer at the selected ages is always higher among the firstborns. For each group and for each selected age, we compare the average log entry wage and the log initial wage in the second and third job, the average log wage at the selected age, and average ages when the first, second and third job started.

Table 12 presents our results. Consider stayers and movers at age 30 (the left panel in the table). On average, stayers started their first job close to three years later than movers, and with a $40 \%$ higher initial wage. By age 30, however, movers were already enjoying a close to $40 \%$ wage premium over stayers, either because they moved quickly to a higher paying job, or because their second and third jobs had steeper age earnings profiles. Movers started on average their second job as early as

(see Willis, 1986, Table 10.5). Heckman et al, 2006, use US Census data and show that log earnings - experience profiles are parallel across schooling levels from 1940 to 1970 and converging from 1980 to 1990.

${ }^{21}$ Since 10.2 and 8.7 percent of laterborns are white collars and in the public sector respectively, the estimated percentage difference is equivalent to a 25.5 and a 35 percent gap. Our results are qualitatively unaltered when we add education as an additional control.

${ }^{22}$ Cappellari, 2002, for Italy and Hartog and Oosterbeek, 1993, for the Netherlands show that age earnings profiles are steeper in the private sector. Conversely, Dustmann and van Soest, 1998, show that profiles are steeper in the German public sector, and Disney et al., 2009 present mixed evidence for the UK. Following Zajonc, 1976, we speculate that firstborns may have had to share with parents the responsibility of growing younger siblings. This could have induced them to invest effort and parental networks to locate a good and stable first job and to keep it for a longer period of time. In support of this view, Table A3 in the Appendix shows that the probability that a firstborn lands a white collar or a public sector job as his first job increases with the number of siblings. 
age 22 and their third job at about age 28. Stayers at age 30, on the other hand, changed their job much later, at age 39 for their second job and at age 44 for their third job.

For both firstborns and laterborns, the average log wage at age 30 can be written as $\log W_{30}=p_{30} \log W_{30}{ }^{S}+\left(1-p_{30}\right) \log W_{30}{ }^{M}$, where the superscripts $S$ and $M$ are for stayers and movers, and $p$ is the probability of being in the first job at age 30 . In the case of firstborns, the log wage is equal to $9.506=0.421 * 9.300+0.579 * 9.656$. In the case of laterborns, it is equal to $9.513=0.356 * 9.250+0.644 * 9.659$. We notice that the average wage for laterborns at age 30 is only about $0.7 \%$ higher than the wage for firstborns (9.513 versus 9.506 ), in spite of the fact that firstborn stayers earn on average $5 \%$ more than laterborn stayers (9.3 versus 9.250$)$. Since the average wage of movers is very similar across birth orders (9.656 versus 9.659), laterborns did catch up by age 30 because they were more likely to have moved by that age into better paid jobs: their probability of having done so was 0.644 rather than 0.579 for firstborns. Similar results hold for wages at age $40 .{ }^{23}$ We conclude that firstborns start with a good match - sometimes a white collar or a public job - and stay in this match for a relatively long period. Laterborns instead struggle from initial low wages to higher wages by hopping quickly to new jobs.

Why do we observe these differences in labour market behaviour? An important reason is education: since firstborns are better educated, they are more likely to locate a good initial match. An additional candidate factor, we believe, is that laterborns are more willing than firstborns to engage in risky behaviour and change employer more frequently. Allen et al, 2005, have shown that the relationship between turnover intentions and turnover is stronger for those lower in risk aversion. In support of this view, the psychological literature has pointed out that laterborns tend to be more rebel and reckless with respect to firstborns ${ }^{24}$, who instead have a tendency to be more conscientious and self-disciplined (see Sulloway, 2007). Psychologists explain these differences by

\footnotetext{
${ }^{23}$ We have also examined whether being firstborn has any effect on experiencing unemployment during the working life, but find no evidence that this is the case.

${ }^{24}$ In his extensive monograph "Born to rebel", Sullloway, 1996, shows descriptive evidence that firstborns have always been more prone to support the status quo, and that laterborns have been more willing to challenge it. Nisbett, 1968, and Sulloway and Zweigenhaft, 2010, respectively show that laterborns are more likely to play risky sports than firstborns, and when playing the same sport they are more likely to carry out riskier moves. Zweigenhaft and von Ammon, 2000, show that being a laterborn positively affects the number of times a college student was arrested. Herrera et al., 2003, show how these findings mirror general beliefs about personality traits of first and laterborns.
} 
referring to the fact that while firstborns are endowed with higher parental resources ${ }^{25}$, laterborns are put under greater pressure to obtain the same returns from more limited resources and thus need to play riskier moves (see Wang et al, 2009).

To verify whether laterborns are less risk averse than firstborns, we use principal component analysis to extract the latent variable $\varrho$ from the vector $\Gamma$, which includes five indicators of risk attitudes: whether the individual has ever bought private retirement accounts and life insurance packages, the body mass index and smoking and drinking habits. ${ }^{26}$ Since this variable increases with risky health behaviours and decreases with the willingness to buy insurance and retirement accounts, we interpret it as a measure of risk taking. We regress $\varrho$ on birth order and the other covariates and report our estimates in Table 13. We find that the effect of being firstborn on the willingness to take risks is negative and statistically significant, independently of whether we control or not for the mediating role of education.

We use these results to augment the human capital model so that it can account for findings a) and b). The augmented Mincerian equation is given by

$$
\ln w_{i t}=a+b_{1} S_{i}+c_{1} x_{i t}+b_{2} S_{i} x_{i t}+d_{1} R_{i}+d_{2} R_{i} x_{i t}+f X_{i}+\lambda_{j}+\eta_{i}+\varepsilon_{i t}
$$

where $S, R$ and $x$ are respectively years of schooling, risk taking attitudes and labour market experience. Dohmen et al, 2007, and Hartog et al, 2003, have shown that wages are increasing in risk taking attitudes $\left(d_{1}>0\right)$. We have shown that firstborns are more risk averse than laterborns, implying that if $O_{i}$ is a dummy for being firstborn and $r_{1}>0$, then

$$
R_{i}=r_{0}-r_{1} O_{i}+z_{i}
$$

Placing (5) into (4) yields

\footnotetext{
${ }^{25}$ See also Lehmann et al., 2012, for evidence on differences in prenatal investments across first and laterborns.

${ }^{26}$ Smoking habits are captured by a dummy indicating whether the individual has ever smoked, and drinking habits by a dummy indicating whether the individual drinks alcohol on a daily basis.
} 
$\ln w_{i t}=\left(a+r_{0} d_{1}\right)+b_{1} S_{i}+\left(c_{1}+r_{0} d_{2}\right) x_{i t}+b_{2} S_{i} x_{i t}-d_{1} r_{1} O_{i}-d_{2} r_{1} O_{i} x_{i t}+f X_{i}+\lambda_{j}+\eta_{i}+\varepsilon_{i t}$

and by taking first differences we obtain

$\Delta \ln w_{i t}=\left(c_{1}+r_{0} d_{2}\right)+b_{2} S_{i}-d_{2} r_{1} O_{i}+\Delta \varepsilon_{i t}$

Using data from the Survey of Consumer Finances, Shaw, 1996, finds that wage growth is positively correlated with preferences for risk taking. In our setup, this implies that $d_{2}>0$, and that firstborns have lower earnings growth, in line with finding b). ${ }^{27}$ To explain finding a), notice that the entry wage is the wage at zero labour market experience $(t=0)$, so that

$\ln w_{i 0}=\left(a+r_{0} d_{1}\right)+b_{1} S_{i}-d_{1} r_{1} O_{i}+f X_{i}+\lambda_{j}+\eta_{i}+\varepsilon_{i 0}$

Furthermore, education is higher among firstborns, so the positive effect of being firstborn on the early wage requires that the positive effect of having higher education more than compensates the negative effect of being less willing to take risks. ${ }^{28}$ The temporary nature of the advantage of being firstborn then follows from finding $b$ ).

\section{Extensions and robustness checks}

In this section, we provide a few extensions and sensitivities to the baseline results discussed in the previous section. First, we report in Table A4 the estimates of birth order effects when single children are excluded from the sample, and show that our results are hardly affected. Second, we investigate sources of heterogeneity in birth order effects by splitting the sample according to

\footnotetext{
27 The learning model could also be augmented by positing that birth order captures other individual attitudes and noncognitive skills accumulated before schooling. This extension would require, however, that employers can observe birth order. This seems unlikely in the presence of rules prohibiting discrimination.

${ }^{28}$ To see this, define $S_{i}=\pi_{0}+\pi_{1} O_{i}+\xi_{i}$ and substitute this in Eq.(7). We obtain that the marginal effect of being firstborn on earnings is $b_{1} \pi_{1}-d_{1} r_{1}$.
} 
whether individuals lived in urban or rural areas at age ten, parental occupation at age ten was in blue or white collar jobs and finally between countries where the prevalent religion is protestant or catholic.

In rural areas, parental preferences for oldest children may have been stronger than in urban areas, with implications for labour market success. The estimates reported in Table A5 show that firstborns who were living in a rural area at age ten earn a higher premium in their first job with respect to laterborns than firstborns who lived in urban area. Yet, since the difference between the estimated coefficients - reported in columns (1) and (2) of the table - is not statistically significant, we consider this evidence as suggestive at best. ${ }^{29}$

Next, we estimate our regressions separately for individuals who had parents in a blue collar or in a white collar job during childhood. We find that firstborns with a blue collar father earn a slightly higher premium over laterborns than firstborns with a white collar father. However, as in the previous case, we cannot reject the hypothesis that the estimated coefficients do not vary by parental group (Table A6). Finally, we report in Table A7 our estimates when the sample is separated in two groups of countries, depending on the prevailing religion in each country. Since protestants see success at work as a manifestation of the benevolence of God, we expect protestant parents to be less likely to favour first or later born children. Therefore, the wage premium in the initial job should be smaller in protestant than in catholic countries. Excluding Germany and Switzerland from the sample, because these two countries are not obviously protestant or catholic, we identify as protestant countries Denmark, Sweden and the Netherlands and as catholic countries the rest (Austria, Italy, Czechia, France and Spain). Our results do not confirm our priors, as we find that the effect of order of birth on wages does not significantly differ across groups of countries.

\section{Conclusions}

While there is substantial empirical research investigating the effects of birth order on educational attainment, little has been done to explore the effects on earnings. The relatively few studies that

\footnotetext{
${ }^{29}$ We test differences between coefficients by using the suest command in Stata 12.
} 
have addressed this issue have found that the effects of birth order on earnings are rather negligible, in spite of the significant effects on educational attainment. This is puzzling if one believes that the key reason why birth order matters for wages is because it affects education.

We have used a sample of 4,280 European males born between 1935 and 1956 to study the effects of birth order on earnings over the life cycle. We have found that firstborns earn on average a $13.7 \%$ premium in their entry wage, but this advantage is completely gone by age 30 . We have also found that being a firstborn has no statistically significant effect on earnings at age 50 or on current earnings, which are typically at a later age. We have estimated the effects of order of birth and education on earnings growth, measured at different points of the working life cycle, and found that both attract a negative and statistically significant coefficient, suggesting that education is not the only "mediator" of birth order effects on earnings.

We have interpreted these results by combining two facts: firstborns have both higher education and higher risk aversion than laterborns. Using these facts, for which we find support both in this paper and in the economic and psychological literature, we have argued that the observed patterns of earnings can be explained by differences in labour turnover. On the one hand, better education is a key reason why firstborns start with a better match. On the other hand, the higher propensity to take risks explains why laterborns change jobs more frequently and enjoy higher wage growth than firstborns.

Our paper emphasizes the importance of using a life cycle approach in the study of the effects of birth order on earnings. This approach allows us to distinguish between temporary and permanent effects, unlike cross - sectional approaches that use a single observation of earnings for each individual. Since we have shown that the effect of birth order varies along the life cycle, choosing a single point in this cycle is likely to yield a misleading view of the relationship between birth order and earnings. 


\section{References}

Allen, D.G., Weeks K.P. \& Moffitt, K.R. (2005). Turnover intentions and voluntary turnover: the moderating roles of self-monitoring, locus of control, proactive personality, and risk aversion., Journal of Applied Psychology, 90, 980-990

Altonji, J. G., \& Pierret, C. R. (2001). Employer learning and statistical discrimination. The Quarterly Journal of Economics, 116(1), 313-350.

Angelini, V., \& Mierau, J. O. (2012). Childhood Health and the Business Cycle: Evidence from Western Europe. HEDG working paper n. 12/28, Department of Economics, University of York.

Bagger, J., Birchenall, J. A., Mansour, H., \& Urzúa, S. (2013). Education, Birth Order, and Family Size, NBER working paper $\mathrm{n} .19111$.

Becker, G.S., \& Lewis, H.G. (1973). Interaction between quantity and quality of children. Journal of Political Economy, 81 (2), pp. S279-S288.

Behrman, J. R., \& Taubman, P. (1986). Birth Order, Schooling, and Earnings. Journal of Labor Economics, 4 (3), pp. S121-S145.

Björklund, A., \& Jäntti, M. (2012). How important is family background for labor-economic outcomes?. Labour Economics, 19(4), 465-474.

Black, S.E., Devereux, P.J., \& Salvanes, K.G. (2005). The more the merrier? The effect of family size and birth order on children's education. Quarterly Journal of Economics, 120 (2), pp. 669-700.

Brunello, G., Weber, G., \& Weiss, C. T. (2012). Books are forever: Early life conditions, education and lifetime earnings in Europe, IZA Discussion Paper n. 6386.

Cappellari, L. (2002). Earnings dynamics and uncertainty in Italy: how do they differ between the private and public sectors?. Labour Economics, 9(4), 477-496.

Clark, A., \& Postel-Vinay, F. (2009). Job security and job protection. Oxford Economic Papers, 61(2), 207-239.

Cunha, F., \& Heckman, J. J. (2007). The Technology of Skill Formation. American Economic Review, 97(2), 31 47.

De Haan, M. (2010). Birth order, family size and educational attainment, Economics of Education Review, 29(4), 576-588.

De Hann, M., Plug, E. \& Rosero, J., (2012), Birth Order and Human Capital Development: Evidence from Ecuador, IZA Discussion Paper 6706

Dohmen, T. et alia (2007) Cross-sectional earnings risk and occupational sorting: The role of risk attitudes. Labour Economics, 14(6), 926-937.

Disney, R., Emmerson, C., \& Tetlow, G. (2009). What is a Public Sector Pension Worth? The Economic Journal, 119(541), F517-F535.

Dustmann, C., \& Van Soest, A. (1998). Public and private sector wages of male workers in Germany. European Economic Review, 42(8), 1417-1441.

Freese, J., Powell, B., \& Steelman, L. C. (1999). Rebel without a cause or effect: Birth order and social attitudes. American Sociological Review, 207-231.

Fuchs, V. R. (1982). Time Preference and Health: An Exploratory Study. In: Fuchs, V.R., Economic Aspects of Health, pp. 93-120. Chicago: University of Chicago Press.

Giuliano, P., \& Spilimbergo, A. (2009). Growing up in a Recession: Beliefs and the Macroeconomy. NBER working paper n.15321.

Hartog, J., \& Oosterbeek, H. (1993). Public and private sector wages in the Netherlands. European Economic Review, 37(1), 97-114. 
Hartog, J., Plug, E, Diaz Serrano, L. and Vieria, J., (2003), Risk Compensation in Wage - a Replication, Empirical Economics, 28:639-647

Heckman, J. J., Lochner, L. J., \& Todd, P. E. (2006). Earnings functions, rates of return and treatment effects: The Mincer equation and beyond. Handbook of the Economics of Education, 1, 307-458.

Heckman, J. J., Stixrud, J., \& Urzua, S. (2006). The effects of cognitive and noncognitive abilities on labor market outcomes and social behavior. NBER working paper n. 12006.

Herrera, N. C., Zajonc, R. B., Wieczorkowska, G., \& Cichomski, B. (2003). Beliefs about birth rank and their reflection in reality. Journal of Personality and Social Psychology, 85(1), 142.

Kantarevic, J., \& Mechoulan, S. (2006). Birth Order, Educational Attainment, and Earnings An Investigation Using the PSID. Journal of Human Resources, 41(4), 755-777.

Kessler, D. (1991). Birth order, family size, and achievement: Family structure and wage determination. Journal of Labor Economics, 9 (4), pp. 413-426.

Kuhn, P., \& Weinberger, C. (2005). Leadership skills and wages, Journal of Labor Economics, 23(3), pp. 395-436

Lange, F. (2007). The speed of employer learning. Journal of Labor Economics, 25(1), 1-35.

Lehmann, J. Y. K., Nuevo-Chiquero, A., \& Vidal-Fernández, M. (2012).Explaining the birth order effect: The role of prenatal and early childhood investments. IZA discussion paper n. 6755.

Lindeboom, M., \& Portrait, F. and Van den Berg, G. J., (2006). Economic conditions early in life and individual mortality. The American Economic Review, 96(1), 290-302.

Lynch, L., \& Black, S. (1998). Beyond the Incidence of Employer-Provided Training, Industrial and Labor Relations Review, 52(1), 64-81

Mantell, R. (2011) How birth order can affect your job salary. Available online at www.marketwatch.com/story/how-birth-order-can-affect-your-job-salary-2011-09-23

Modin, B. (2002). Birth order and mortality: a life-long follow-up of 14,200 boys and girls born in early 20th century Sweden. Social science \& medicine, 54(7), 1051-1064.

Murphy, K. M., \& Welch, F. (1990). Empirical age-earnings profiles. Journal of Labor Economics, 202-229.

Nisbett, R. E. (1968). Birth order and participation in dangerous sports. Journal of personality and social psychology, 8, 351 .

Olneck, M. R., \& Bills, D. B. (1979). Family configuration and achievement: Effects of birth order and family size in a sample of brothers. Social Psychology Quarterly, 135-148.

Oreopoulos, P., von Wachter, T., \& Heisz, A. (2012). The short-and long-term career effects of graduating in a recession. American Economic Journal: Applied Economics, 4(1), 1-29.

Price, J. (2008). Parent-Child Quality Time Does Birth Order Matter?. Journal of Human Resources, 43(1), 240265.

Shaw, K. L.,(1996). An Empirical Analysis of Risk Aversion and Income Growth. Journal of Labor Economics, 14 (4), 626-653.

Sulloway, F. J. (2007). Birth order and sibling competition. The Oxford handbook of evolutionary psychology, 297311.

Sulloway, F. J. (1996). Born to rebel: Birth Order, Family Dynamics, and Creative Lives. Pantheon Books.

Sulloway, F.J., \& Zweigenhaft, R.L. (2010). Birth Order and Risk Taking in Athletics: A Meta-analysis and Study of Major League Baseball Players. Personality and Social Psychology Review, 14, 402-416.

Wang, X. T., Kruger, D. J., \& Wilke, A. (2009). Life history variables and risk-taking propensity. Evolution and Human Behavior, 30(2), 77-84.

Weiss, C. (2012). Two Measures of Lifetime Resources for Europe using SHARELIFE. SHARE Working Paper Series, 06-2012.

Willis, R. J. (1986). Wage determinants: A survey and reinterpretation of human capital earnings functions. In: O. Ashenfelter \& R. Layard (eds.), Handbook of Labor Economics, volume 1, chapter 10, pages 525-602 
Zajonc, R. B. (1976). Family configuration and intelligence: Variations in scholastic aptitude scores parallel trends in family size and the spacing of children. Science.

Zweigenhaft, R. L., \& Von Ammon, J. (2000). Birth order and civil disobedience: A test of Sulloway's "born to rebel" hypothesis. The Journal of Social Psychology, 140(5), 624-627. 


\section{Tables}

Table 1. Distribution of the number of brothers and sisters in the household at age ten

\begin{tabular}{lcc}
\hline Number of siblings at age ten & Oldest child & $\begin{array}{c}\text { Intermediate or } \\
\text { youngest child }\end{array}$ \\
\hline 1 & 24.09 & 0 \\
2 & 36.64 & 26.50 \\
3 & 20.26 & 26.33 \\
4 & 10.50 & 18.35 \\
5 & 4.28 & 10.72 \\
6 & 2.00 & 6.69 \\
7 & 1.14 & 4.71 \\
8 & 0.57 & 3.09 \\
9 & 0.06 & 1.15 \\
$10+$ & 0.46 & 2.45 \\
\hline
\end{tabular}


Table 2. Summary statistics, by birth order

\begin{tabular}{|c|c|c|c|c|c|c|}
\hline & Mean & $\begin{array}{l}\text { Standard } \\
\text { deviation }\end{array}$ & $\begin{array}{l}\text { Number } \\
\text { of obs. }\end{array}$ & Mean & $\begin{array}{l}\text { Standard } \\
\text { deviation }\end{array}$ & $\begin{array}{l}\text { Number of } \\
\text { obs. }\end{array}$ \\
\hline & & $\begin{array}{l}\text { Oldest } \\
\text { sibling }\end{array}$ & & & $\begin{array}{l}\text { Other } \\
\text { sibling }\end{array}$ & \\
\hline First wage & $11,786.46$ & $11,931.81$ & 1,752 & $10,577.37$ & $13,055.06$ & 2,528 \\
\hline Second wage & $18,145.44$ & $17,149.13$ & 1,276 & $16,343.13$ & $15,476.64$ & 1,981 \\
\hline Third wage & $22,307.85$ & $19,460.54$ & 849 & $20,541.04$ & $16,688.16$ & 1,364 \\
\hline Wage at 30 & $18,281.29$ & $15,213.39$ & 1,718 & $18,641.52$ & $15,837.45$ & 2,473 \\
\hline Wage at 40 & $22,162.24$ & $17,644.81$ & 1,741 & $21,586.36$ & $16,490.78$ & 2,503 \\
\hline Wage at 50 & $23,723.05$ & $17,132.32$ & 1,703 & $22,625.79$ & $15,799.70$ & 2,437 \\
\hline Current or last wage & $23,546.84$ & $15,161.50$ & 1,752 & $22,787.13$ & $15,169.60$ & 2,528 \\
\hline Lifetime earnings net of pensions & $8,844.11$ & $5,580.00$ & 1,752 & $8,676.27$ & $5,486.53$ & 2,528 \\
\hline Not employed at age 30 & 0.019 & 0.138 & 1,752 & 0.022 & 0.146 & 2,528 \\
\hline Not employed at age 40 & 0.006 & 0.079 & 1,752 & 0.010 & 0.099 & 2,528 \\
\hline Not employed at age 50 & 0.028 & 0.165 & 1,752 & 0.036 & 0.186 & 2,528 \\
\hline Age when first job started & 19.602 & 4.165 & 1,752 & 18.587 & 4.060 & 2,528 \\
\hline Age when last job ended & 58.163 & 4.429 & 1,752 & 57.786 & 4.404 & 2,528 \\
\hline Oldest child & 1 & - & 1,752 & 0 & - & 2,528 \\
\hline Only child & 0.241 & 0.428 & 1,752 & 0 & - & 2,528 \\
\hline Number of siblings & 2.512 & 1.456 & 1,752 & 3.917 & 1.944 & 2,528 \\
\hline Mother in the house at ten & 0.965 & 0.183 & 1,752 & 0.972 & 0.165 & 2,528 \\
\hline Father in the house at ten & 0.913 & 0.282 & 1,752 & 0.930 & 0.255 & 2,528 \\
\hline Foster mother in the house at ten & 0.021 & 0.142 & 1,752 & 0.011 & 0.105 & 2,528 \\
\hline Foster father in the house at ten & 0.032 & 0.176 & 1,752 & 0.017 & 0.128 & 2,528 \\
\hline Grandparents in the house at ten & 0.147 & 0.354 & 1,752 & 0.106 & 0.308 & 2,528 \\
\hline Other relatives in the house at ten & 0.059 & 0.236 & 1,752 & 0.049 & 0.215 & 2,528 \\
\hline Other non-relatives in the house at ten & 0.016 & 0.125 & 1,752 & 0.022 & 0.146 & 2,528 \\
\hline Hunger episodes before age 15 & 0.031 & 0.174 & 1,752 & 0.042 & 0.200 & 2,528 \\
\hline $\begin{array}{l}\text { Parents smoke, drank or had mental } \\
\text { problems }\end{array}$ & 0.691 & 0.462 & 1,752 & 0.700 & 0.458 & 2,528 \\
\hline At least one parent died before turning & & & & & & \\
\hline $35-1+2+1+0$ & 0.038 & 0.192 & 1,752 & 0.017 & 0.129 & 2,528 \\
\hline Breadwinner at ten is blue collar & 0.661 & 0.474 & 1,752 & 0.722 & 0.448 & 2,528 \\
\hline Lived in rural area & 0.378 & 0.485 & 1,752 & 0.439 & 0.496 & 2,528 \\
\hline Years of education & 12.593 & 4.091 & 1,752 & 11.487 & 4.250 & 2,528 \\
\hline Age of mother at birth & 23.876 & 3.960 & 764 & 27.671 & 4.707 & 692 \\
\hline
\end{tabular}

Source: SHARE survey waves 1, 2 and 3. 
Table 3. Birth order effects on education, by number of siblings. Dependent variable: number of years of schooling

$$
\text { Two siblings Three siblings Four siblings All siblings }
$$

\begin{tabular}{lcccc} 
Oldest child & $0.749^{* * *}$ & $0.676^{* * *}$ & $0.706^{* *}$ & $0.645^{* * *}$ \\
& $(0.205)$ & $(0.248)$ & $(0.336)$ & $(0.123)$ \\
Number of siblings & - & - & - & $-0.123^{* * *}$ \\
& & & & $(0.032)$ \\
& 1,312 & 1,021 & 648 & 4,280 \\
Observations & 0.243 & 0.253 & 0.320 & 0.254 \\
\hline
\end{tabular}

Notes: All regressions include dummies for: cohort, country, mother in the house at 10, father in the house at 10, foster mother in the house at 10 , foster father in the house at 10 , grandparents in the house at 10 , other relatives in the house at 10 , hunger episodes by age 15 , parents smoked, drank or had mental problems, at least one parent died by age 35, breadwinner occupation at age 10 , lived in rural area at age 10 .

Robust standard errors in parentheses. One, two and three stars for statistical significance at the 10, 5 and 1 percent level of confidence.

Table 4. Birth order effects on real earnings. By family size and pooling sizes. Dependent variable: log real wage

\begin{tabular}{|c|c|c|c|c|c|c|c|c|}
\hline & $\begin{array}{c}\text { Entry } \\
\text { wage } \\
2 \text { siblings }\end{array}$ & $\begin{array}{c}\text { Entry } \\
\text { wage } \\
3 \text { siblings }\end{array}$ & $\begin{array}{c}\text { Entry } \\
\text { wage } \\
4 \text { siblings }\end{array}$ & $\begin{array}{l}\text { Entry wage } \\
\text { all siblings }\end{array}$ & $\begin{array}{l}\text { Wage in } \\
\text { current or } \\
\text { last job } \\
2 \text { siblings }\end{array}$ & $\begin{array}{l}\text { Wage in } \\
\text { current or } \\
\text { last job } \\
3 \text { siblings }\end{array}$ & $\begin{array}{l}\text { Wage in } \\
\text { current or } \\
\text { last job } \\
4 \text { siblings }\end{array}$ & $\begin{array}{l}\text { Wage in } \\
\text { current or } \\
\text { last job all } \\
\text { siblings }\end{array}$ \\
\hline Oldest child & $\begin{array}{c}0.135^{* *} \\
(0.056)\end{array}$ & $\begin{array}{c}0.145^{* *} \\
(0.064)\end{array}$ & $\begin{array}{l}0.186^{*} \\
(0.098)\end{array}$ & $\begin{array}{c}0.137 * * * \\
(0.033)\end{array}$ & $\begin{array}{c}0.004 \\
(0.031)\end{array}$ & $\begin{array}{l}-0.023 \\
(0.039)\end{array}$ & $\begin{array}{c}0.030 \\
(0.057)\end{array}$ & $\begin{array}{l}-0.011 \\
(0.020)\end{array}$ \\
\hline $\begin{array}{l}\text { Number of } \\
\text { siblings }\end{array}$ & - & - & - & $\begin{array}{c}-0.032^{* * *} \\
(0.009)\end{array}$ & - & - & - & $\begin{array}{c}-0.021 * * * \\
(0.005)\end{array}$ \\
\hline Observations & 1,312 & 1,021 & 648 & 4,280 & 1,312 & 1,021 & 648 & 4,280 \\
\hline R Squared & 0.236 & 0.255 & 0.250 & 0.233 & 0.244 & 0.264 & 0.227 & 0.210 \\
\hline
\end{tabular}

Notes: All regressions include dummies for: cohort, country, mother in the house at 10, father in the house at 10, foster mother in the house at 10 , foster father in the house at 10, grandparents in the house at 10, other relatives in the house at 10, hunger episodes by age 15 , parents smoked, drank or had mental problems, at least one parent died by age 35, breadwinner occupation at age 10 , lived in rural area at age 10 . Robust standard errors in parentheses. One, two and three stars for statistical significance at the 10,5 and 1 percent level of confidence. 
Table 5. Birth order effects on earnings - by pooling family sizes

\begin{tabular}{|c|c|c|c|c|c|c|}
\hline & Entry wage & $\begin{array}{c}\text { Wage at } \\
30\end{array}$ & $\begin{array}{l}\text { Wage at } \\
40\end{array}$ & $\begin{array}{c}\text { Wage at } \\
50\end{array}$ & $\begin{array}{l}\text { Wage in } \\
\text { current or } \\
\text { last job }\end{array}$ & $\begin{array}{l}\text { Lifetime } \\
\text { earnings }\end{array}$ \\
\hline Oldest child & $\begin{array}{c}0.137 * * * \\
(0.033)\end{array}$ & $\begin{array}{l}-0.024 \\
(0.026)\end{array}$ & $\begin{array}{l}-0.002 \\
(0.023)\end{array}$ & $\begin{array}{c}0.007 \\
(0.022)\end{array}$ & $\begin{array}{l}-0.011 \\
(0.020)\end{array}$ & $\begin{array}{c}0.000 \\
(0.019)\end{array}$ \\
\hline Number of siblings & $\begin{array}{c}-0.032^{* * *} \\
(0.009)\end{array}$ & $\begin{array}{l}-0.011 \\
(0.007)\end{array}$ & $\begin{array}{c}-0.015^{* *} \\
(0.007)\end{array}$ & $\begin{array}{c}-0.018^{* * *} \\
(0.006)\end{array}$ & $\begin{array}{c}-0.021 * * * \\
(0.005)\end{array}$ & $\begin{array}{c}-0.015^{* * *} \\
(0.006)\end{array}$ \\
\hline Observations & 4,280 & 4,191 & 4,244 & 4,140 & 4,280 & 4,280 \\
\hline R-squared & 0.233 & 0.221 & 0.208 & 0.205 & 0.210 & 0.266 \\
\hline
\end{tabular}

Notes: All regressions include dummies for: cohort, country, mother in the house at 10, father in the house at 10, foster mother in the house at 10 , foster father in the house at 10, grandparents in the house at 10, other relatives in the house at 10, hunger episodes by age 15, parents smoked, drank or had mental problems, at least one parent died by age 35, breadwinner occupation at age 10 , lived in rural area at age 10 . Robust standard errors in parentheses. One, two and three stars for statistical significance at the 10, 5 and 1 percent level of confidence.

Table 6. Birth order effects on earnings - with and without imputation

\begin{tabular}{lcccc}
\hline & $\begin{array}{c}\text { Entry wage } \\
\text { no } \\
\text { imputation }\end{array}$ & $\begin{array}{c}\text { Entry wage } \\
\text { with } \\
\text { imputation }\end{array}$ & $\begin{array}{c}\text { Wage in current } \\
\text { or last job no } \\
\text { imputation }\end{array}$ & $\begin{array}{c}\text { Wage in current or } \\
\text { last job with } \\
\text { imputation }\end{array}$ \\
Oldest child & $0.129 * * *$ & $0.137 * * *$ & -0.011 & -0.011 \\
Number of siblings & $(0.040)$ & $(0.033)$ & $(0.020)$ & $(0.020)$ \\
& $-0.034^{* * *}$ & $-0.032^{* * *}$ & $-0.021 * * *$ & $-0.021^{* * *}$ \\
Observations & $(0.011)$ & $(0.009)$ & $(0.005)$ & $(0.005)$ \\
R-squared & 3,262 & 4,280 & 4,278 & 4,280 \\
\hline
\end{tabular}

Notes: All regressions include dummies for: cohort, country, mother in the house at 10, father in the house at 10, foster mother in the house at 10 , foster father in the house at 10, grandparents in the house at 10, other relatives in the house at 10, hunger episodes by age 15 , parents smoked, drank or had mental problems, at least one parent died by age 35, breadwinner occupation at age 10, lived in rural area at age 10 . Robust standard errors in parentheses. One, two and three stars for statistical significance at the 10, 5 and 1 percent level of confidence. 
Table 7. Birth order effects on earnings - with and without controls for age of mother at birth

\begin{tabular}{lcccc}
\hline & Entry wage & $\begin{array}{c}\text { Entry } \\
\text { wage }\end{array}$ & $\begin{array}{c}\text { Wage in } \\
\text { current or } \\
\text { last job }\end{array}$ & $\begin{array}{c}\text { Wage in } \\
\text { current or last } \\
\text { job }\end{array}$ \\
Oldest child & $\begin{array}{c}0.187^{* * *} \\
(0.060)\end{array}$ & $\begin{array}{c}0.175^{* * *} \\
(0.057)\end{array}$ & $\begin{array}{c}0.005 \\
(0.035)\end{array}$ & -0.015 \\
Number of siblings & $-0.047^{* * *}$ & $-0.048^{* * *}$ & $-0.022^{* *}$ & $-0.022^{* *}$ \\
Age of mother at & $(0.017)$ & $(0.017)$ & $(0.010)$ & $(0.010)$ \\
birth & 0.003 & - & 0.005 & - \\
Observations & $(0.007)$ & & & \\
R-squared & 1,456 & 1,456 & 1,456 & 1,456 \\
\hline
\end{tabular}

Notes: All regressions include dummies for: cohort, country, mother in the house at 10, father in the house at 10, foster mother in the house at 10 , foster father in the house at 10 , grandparents in the house at 10 , other relatives in the house at 10 , hunger episodes by age 15 , parents smoked, drank or had mental problems, at least one parent died by age 35, breadwinner occupation at age 10 , lived in rural area at age 10 .

Robust standard errors in parentheses. One, two and three stars for statistical significance at the 10, 5 and 1 percent level of confidence.

Table 8. Birth order effects on wage growth over the life cycle

\begin{tabular}{lcccc}
\hline & $\begin{array}{c}\text { Wage at } 30- \\
\text { Entry wage }\end{array}$ & $\begin{array}{c}\text { Wage at } 40- \\
\text { Entry wage }\end{array}$ & $\begin{array}{c}\text { Wage at } 50- \\
\text { Entry wage }\end{array}$ & $\begin{array}{c}\text { Wage in current } \\
\text { or last job } \\
\text { - first wage }\end{array}$ \\
Oldest child & $-0.162^{* * *}$ & $-0.135^{* * *}$ & $-0.142^{* * *}$ & $-0.148^{* * *}$ \\
Number of & $(0.033)$ & $(0.035)$ & $(0.035)$ & $(0.036)$ \\
siblings & $0.022^{* *}$ & 0.016 & 0.013 & 0.011 \\
& $(0.010)$ & $(0.010)$ & $(0.010)$ & $(0.010)$ \\
Observations & 4,191 & 4,244 & 4,140 & 4,280 \\
R-squared & 0.082 & 0.096 & 0.106 & 0.137 \\
\hline
\end{tabular}

Notes: All regressions include dummies for: cohort, country, mother in the house at 10 , father in the house at 10, foster mother in the house at 10 , foster father in the house at 10, grandparents in the house at 10, other relatives in the house at 10, hunger episodes by age 15 , parents smoked, drank or had mental problems, at least one parent died by age 35, breadwinner occupation at age 10, lived in rural area at age 10 . Robust standard errors in parentheses. One, two and three stars for statistical significance at the 10, 5 and 1 percent level of confidence. 
Table 9. Birth order and education effects on wage growth over the life cycle

\begin{tabular}{lcccc}
\hline & $\begin{array}{c}\text { Wage at } 30- \\
\text { Entry wage }\end{array}$ & $\begin{array}{c}\text { Wage at } 40- \\
\text { Entry wage }\end{array}$ & $\begin{array}{c}\text { Wage at } 50- \\
\text { Entry wage }\end{array}$ & $\begin{array}{c}\text { Wage in curren } \\
\text { or last job } \\
\text { - first wage }\end{array}$ \\
Oldest child & $-0.131^{* * *}$ & $-0.103^{* * *}$ & $-0.110^{* * *}$ & $-0.119^{* * *}$ \\
& $(0.033)$ & $(0.035)$ & $(0.035)$ & $(0.036)$ \\
Years of & $-0.049^{* * *}$ & $-0.050^{* * *}$ & $-0.048^{* * *}$ & $-0.045^{* * *}$ \\
schooling & $(0.004)$ & $(0.004)$ & $(0.004)$ & $(0.005)$ \\
Number of & $0.016^{*}$ & 0.010 & 0.007 & 0.005 \\
siblings & $(0.010)$ & $(0.010)$ & $(0.010)$ & $(0.010)$ \\
Observations & 4,191 & 4,244 & 4,140 & 4,280 \\
R-squared & 0.110 & 0.123 & 0.132 & 0.156 \\
\hline
\end{tabular}

Notes: All regressions include dummies for: cohort, country, mother in the house at 10, father in the house at 10, foster mother in the house at 10 , foster father in the house at 10, grandparents in the house at 10, other relatives in the house at 10, hunger episodes by age 15 , parents smoked, drank or had mental problems, at least one parent died by age 35 , breadwinner occupation at age 10 , lived in rural area at age 10 . Robust standard errors in parentheses. One, two and three stars for statistical significance at the 10,5 and 1 percent level of confidence.

Table 10. Birth order, number of jobs held and type of first job

\begin{tabular}{lcccc}
\hline \multicolumn{1}{l}{$\begin{array}{c}\text { Had more } \\
\text { than one job }\end{array}$} & $\begin{array}{c}\text { First job was } \\
\text { full time }\end{array}$ & $\begin{array}{c}\text { First job was } \\
\text { white collar }\end{array}$ & $\begin{array}{c}\text { First job was in } \\
\text { public sector }\end{array}$ \\
Oldest child & $-0.041^{* * *}$ & -0.004 & $0.029 * * *$ & $0.036^{* * *}$ \\
& $(0.014)$ & $(0.006)$ & $(0.010)$ & $(0.010)$ \\
Number of siblings & 0.001 & 0.002 & -0.003 & -0.000 \\
& $(0.004)$ & $(0.002)$ & $(0.002)$ & $(0.003)$ \\
& & & & \\
Observations & 4,280 & 4,280 & 4,275 & 4,280 \\
R-squared & 0.0654 & 0.030 & 0.118 & 0.062 \\
\hline
\end{tabular}

Notes: All regressions include dummies for: cohort, country, mother in the house at 10, father in the house at 10, foster mother in the house at 10 , foster father in the house at 10 , grandparents in the house at 10 , other relatives in the house at 10 , hunger episodes by age 15 , parents smoked, drank or had mental problems, at least one parent died by age 35, breadwinner occupation at age 10, lived in rural area at age 10 . Robust standard errors in parentheses. One, two and three stars for statistical significance at the 10, 5 and 1 percent level of confidence. 
Table 11. Birth order effects on the probability of being still in the first job at selected ages

Number of siblings
Still in first job at 30

Oldest child

\section{$0.058 * * *$}

$$
(0.016)
$$

$-0.004$

4,191

0.084
Still in first job at 40

$0.051 * * *$

$-0.003$

Observations

R-squared

4,244

0.083

Notes: All regressions include dummies for: cohort, country, mother in the house at 10 , father in the house at 10 , foster mother in the house at 10 , foster father in the house at 10, grandparents in the house at 10, other relatives in the house at 10, hunger episodes by age 15 , parents smoked, drank or had mental problems, at least one parent died by age 35 , breadwinner occupation at age 10 , lived in rural area at age 10 . Robust standard errors in parentheses. One, two and three stars for statistical significance at the 10, 5 and 1 percent level of confidence. 
Table 12. Labour turnover and earnings growth

\begin{tabular}{lc|lc}
\multicolumn{1}{c}{ Age 30 } & Mean & & Mean \\
& & & \\
& & Still in first job & \\
Still in first job & 9.273 & Log wage at 40 & \\
Log wage at 30 & 9.058 & Log first wage & 9.395 \\
Log first wage & 9.857 & Log second wage & 9.000 \\
Log second job & 9.944 & Log third wage & 9.776 \\
Log third job & 20.589 & Age started first job & 9.850 \\
Age started first job & 51.214 & Age ended first job & 20.462 \\
Age ended first job & 39.225 & Age started second job & 56.130 \\
Age started second job & 43.883 & Age started third job & 47.666 \\
Age started third job & & & 50.975 \\
& & Not in first job anymore & \\
Not in first job anymore & 9.658 & Log wage at 35 & 9.869 \\
Log wage at 30 & 8.604 & Log first wage & 8.698 \\
Log first wage & 9.232 & Log second wage & 9.319 \\
Log second job & 9.622 & Log third wage & 9.655 \\
Log third job & 17.865 & Age started first job & 18.421 \\
Age started first job & 21.471 & Age ended first job & 23.545 \\
Age ended first job & 21.977 & Age started second job & 22.842 \\
Age started second job & 27.784 & Age started third job & 29.023 \\
Age started third job & &
\end{tabular}


Table 13. Birth order, education and the propensity to take risks

\begin{tabular}{|c|c|c|}
\hline Oldest child & $\begin{array}{c}-0.071^{* *} \\
(0.028)\end{array}$ & $\begin{array}{c}-0.058^{* *} \\
(0.028)\end{array}$ \\
\hline Years of schooling & - & $\begin{array}{c}-0.021 * * * \\
(0.003)\end{array}$ \\
\hline Number of siblings & $\begin{array}{c}0.006 \\
(0.007)\end{array}$ & $\begin{array}{c}0.004 \\
(0.007)\end{array}$ \\
\hline
\end{tabular}

$\begin{array}{lll}\text { Observations } & 3,929 & 3,929\end{array}$

R-squared $0.189 \quad 0.197$

Notes: All regressions include dummies for: cohort, country, mother in the house at 10, father in the house at 10, foster mother in the house at

10 , foster father in the house at 10, grandparents in the house at 10, other relatives in the house at 10, hunger episodes by age 15 , parents

smoked, drank or had mental problems, at least one parent died by age 35 , breadwinner occupation at age 10 , lived in rural area at age 10 .

Robust standard errors in parentheses. One, two and three stars for statistical significance at the 10, 5 and 1 percent level of confidence. 


\section{APPENDIX}

Table A1. Summary statistics

\begin{tabular}{|c|c|c|c|}
\hline & Mean & $\begin{array}{l}\text { Standard } \\
\text { deviation }\end{array}$ & $\begin{array}{l}\text { Number of } \\
\text { observations }\end{array}$ \\
\hline First wage & $11,072.31$ & $12,619.95$ & 4,280 \\
\hline Second wage & $17,049.22$ & $16,173.88$ & 3,257 \\
\hline Third wage & $21,218.86$ & $17,819.29$ & 2,213 \\
\hline Wage at 30 & $18,493.85$ & $15,583.83$ & 4,191 \\
\hline Wage at 40 & $21,822.60$ & $16,974.00$ & 4,244 \\
\hline Wage at 50 & $23,077.15$ & $16,367.90$ & 4,140 \\
\hline Current or last wage & $23,098.11$ & $15,169.12$ & 4,280 \\
\hline Lifetime earnings net of pensions & $8,744.98$ & $5,524.95$ & 4,280 \\
\hline Not employed at age 30 & 0.021 & 0.143 & 4,280 \\
\hline Not employed at age 40 & 0.008 & 0.091 & 4,280 \\
\hline Not employed at age 50 & 0.033 & 0.178 & 4,280 \\
\hline Age when first job started & 19.002 & 4.133 & 4,280 \\
\hline Age when last job ended & 57.940 & 4.418 & 4,280 \\
\hline Oldest child & 0.409 & 0.492 & 4,280 \\
\hline Only child & 0.099 & 0.298 & 4,280 \\
\hline Number of siblings & 3.342 & 1.891 & 4,280 \\
\hline Mother in the house at ten & 0.969 & 0.173 & 4,280 \\
\hline Father in the house at ten & 0.923 & 0.266 & 4,280 \\
\hline Foster mother in the house at ten & 0.015 & 0.121 & 4,280 \\
\hline Foster father in the house at ten & 0.023 & 0.150 & 4,280 \\
\hline Grandparents in the house at ten & 0.123 & 0.328 & 4,280 \\
\hline Other relatives in the house at ten & 0.053 & 0.224 & 4,280 \\
\hline Other non-relatives in the house at ten & 0.019 & 0.138 & 4,280 \\
\hline Hunger episodes before age 15 & 0.037 & 0.190 & 4,280 \\
\hline Parents smoke, drank or had mental problems & 0.696 & 0.460 & 4,280 \\
\hline At least one parent died before turning 35 & 0.026 & 0.158 & 4,280 \\
\hline Breadwinner at ten is blue collar & 0.697 & 0.460 & 4,280 \\
\hline Lived in rural area & 0.414 & 0.493 & 4,280 \\
\hline Years of education & 11.940 & 4.220 & 4,280 \\
\hline Age of mother at birth & 25.679 & 4.727 & 1,456 \\
\hline
\end{tabular}

Source: SHARE survey waves 1, 2 and 3. 
Table A2. Birth order effects on the probability of not being employed at different ages

\begin{tabular}{|c|c|c|c|c|c|c|}
\hline & $\begin{array}{c}\text { Not } \\
\text { employed at } \\
20\end{array}$ & $\begin{array}{c}\text { Not } \\
\text { employed } \\
\text { at } 25\end{array}$ & $\begin{array}{c}\text { Not } \\
\text { employed at } \\
30\end{array}$ & $\begin{array}{c}\text { Not } \\
\text { employed } \\
\text { at } 35\end{array}$ & $\begin{array}{c}\text { Not } \\
\text { employed at } \\
40\end{array}$ & $\begin{array}{c}\text { Not } \\
\text { employed at } \\
50\end{array}$ \\
\hline Oldest Child & $\begin{array}{c}0.072^{* * *} \\
(0.015)\end{array}$ & $\begin{array}{c}0.029 * * * \\
(0.010)\end{array}$ & $\begin{array}{l}-0.004 \\
(0.005)\end{array}$ & $\begin{array}{l}-0.000 \\
(0.003)\end{array}$ & $\begin{array}{l}-0.002 \\
(0.003)\end{array}$ & $\begin{array}{l}-0.004 \\
(0.006)\end{array}$ \\
\hline Number of Siblings & $\begin{array}{c}-0.008^{*} \\
(0.004)\end{array}$ & $\begin{array}{l}-0.000 \\
(0.002)\end{array}$ & $\begin{array}{l}-0.001 \\
(0.001)\end{array}$ & $\begin{array}{c}0.000 \\
(0.001)\end{array}$ & $\begin{array}{c}0.000 \\
(0.001)\end{array}$ & $\begin{array}{c}0.002 \\
(0.002)\end{array}$ \\
\hline Observations & 4,280 & 4,280 & 4,280 & 4,280 & 4,280 & 4,280 \\
\hline R-squared & 0.119 & 0.069 & 0.021 & 0.014 & 0.018 & 0.023 \\
\hline
\end{tabular}

Notes: All regressions include dummies for: cohort, country, mother in the house at 10, father in the house at 10, foster mother in the house at 10 , foster father in the house at 10, grandparents in the house at 10, other relatives in the house at 10, hunger episodes by age 15 , parents smoked, drank or had mental problems, at least one parent died by age 35, breadwinner occupation at age 10 , lived in rural area at age 10 . Robust standard errors in parentheses. One, two and three stars for statistical significance at the 10, 5 and 1 percent level of confidence.

Table A3. Birth order, number of jobs held and type of first job. By number of siblings

\begin{tabular}{lcccc}
\hline & $\begin{array}{c}\text { First job } \\
\text { white collar, } \\
\text { at most } 3 \\
\text { siblings }\end{array}$ & $\begin{array}{c}\text { First job was full time, } 4 \\
\text { siblings or more }\end{array}$ & $\begin{array}{c}\text { First job was in } \\
\text { public sector, at } \\
\text { most 3 siblings }\end{array}$ & $\begin{array}{c}\text { First job was in } \\
\text { public sector, } 4 \\
\text { siblings or more }\end{array}$ \\
Oldest child & 0.019 & $0.040 * *$ & $0.031 * *$ & $0.049 * *$ \\
Number of siblings & $(0.013)$ & $(0.019)$ & $(0.013)$ & $(0.021)$ \\
& -0.008 & -0.005 & -0.004 & -0.002 \\
Observations & $(0.009)$ & $(0.004)$ & $(0.009)$ & $(0.004)$ \\
R-squared & 2,755 & 1,520 & & 1,525 \\
\hline
\end{tabular}

Notes: All regressions include dummies for: cohort, country, mother in the house at 10, father in the house at 10, foster mother in the house at 10 , foster father in the house at 10, grandparents in the house at 10, other relatives in the house at 10, hunger episodes by age 15 , parents smoked, drank or had mental problems, at least one parent died by age 35 , breadwinner occupation at age 10, lived in rural area at age 10 . Robust standard errors in parentheses. One, two and three stars for statistical significance at the 10, 5 and 1 percent level of confidence. 
Table A4. Birth order effects, excluding single children

\begin{tabular}{|c|c|c|c|}
\hline & Entry wage & $\begin{array}{c}\text { Wage in } \\
\text { current or last } \\
\text { job }\end{array}$ & $\begin{array}{c}\text { Wage in } \\
\text { current or last } \\
\text { job - entry } \\
\text { wage }\end{array}$ \\
\hline Oldest Child & $\begin{array}{c}0.140 * * * \\
(0.035)\end{array}$ & $\begin{array}{l}-0.015 \\
(0.021)\end{array}$ & $\begin{array}{c}-0.155^{* * *} \\
(0.038)\end{array}$ \\
\hline Number of Siblings & $\begin{array}{c}-0.034^{* * *} \\
(0.010)\end{array}$ & $\begin{array}{c}-0.021 * * * \\
(0.006)\end{array}$ & $\begin{array}{c}0.013 \\
(0.011)\end{array}$ \\
\hline Observations & 3,858 & 3,858 & 3,858 \\
\hline R-squared & 0.225 & 0.205 & 0.135 \\
\hline
\end{tabular}

Table A5. Birth order effects on earnings, by rural and urban areas

\begin{tabular}{|c|c|c|c|c|c|c|}
\hline & $\begin{array}{l}\text { Entry wage. } \\
\text { Rural }\end{array}$ & $\begin{array}{c}\text { Entry wage. } \\
\text { Urban }\end{array}$ & $\begin{array}{l}\text { Wage in } \\
\text { current or last } \\
\text { job. Rural }\end{array}$ & $\begin{array}{l}\text { Wage in } \\
\text { current or last } \\
\text { job. Urban }\end{array}$ & $\begin{array}{l}\text { Wage in current } \\
\text { or last job - } \\
\text { entry wage. } \\
\text { Rural }\end{array}$ & $\begin{array}{c}\text { Current or last } \\
\text { wage - first wage. } \\
\text { Urban }\end{array}$ \\
\hline Oldest child & $\begin{array}{c}0.168^{* * *} \\
(0.051)\end{array}$ & $\begin{array}{c}0.121 * * * \\
(0.044)\end{array}$ & $\begin{array}{l}-0.021 \\
(0.029)\end{array}$ & $\begin{array}{l}-0.010 \\
(0.027)\end{array}$ & $\begin{array}{c}-0.189 * * * \\
(0.056)\end{array}$ & $\begin{array}{c}-0.130^{* * *} \\
(0.048)\end{array}$ \\
\hline Number siblings & $\begin{array}{l}-0.015 \\
(0.014)\end{array}$ & $\begin{array}{c}-0.048^{* * *} \\
(0.013)\end{array}$ & $\begin{array}{l}-0.011 \\
(0.008)\end{array}$ & $\begin{array}{c}-0.031 * * * \\
(0.008)\end{array}$ & $\begin{array}{c}0.004 \\
(0.015)\end{array}$ & $\begin{array}{c}0.016 \\
(0.014)\end{array}$ \\
\hline Observations & 1,772 & 2,508 & 1,772 & 2,508 & 1,772 & 2,508 \\
\hline R-squared & 0.212 & 0.264 & 0.271 & 0.182 & 0.130 & 0.161 \\
\hline
\end{tabular}

Notes: All regressions include dummies for: cohort, country, mother in the house at 10, father in the house at 10, foster mother in the house at 10 , foster father in the house at 10, grandparents in the house at 10, other relatives in the house at 10, hunger episodes by age 15 , parents smoked, drank or had mental problems, at least one parent died by age 35, breadwinner occupation at age 10 , lived in rural area at age 10 . Robust standard errors in parentheses. One, two and three stars for statistical significance at the 10, 5 and 1 percent level of confidence. 
Table A6. Birth order effects on earnings, by parental occupation

\begin{tabular}{|c|c|c|c|c|c|c|}
\hline & $\begin{array}{l}\text { Entry wage. } \\
\text { White collar } \\
\text { breadwinner }\end{array}$ & $\begin{array}{l}\text { Entry wage. } \\
\text { Blue collar } \\
\text { breadwinner }\end{array}$ & $\begin{array}{l}\text { Wage in current } \\
\text { or last job. } \\
\text { White collar } \\
\text { breadwinner }\end{array}$ & $\begin{array}{l}\text { Wage in current or } \\
\text { last job. Blue collar } \\
\text { breadwinner }\end{array}$ & $\begin{array}{l}\text { Wage in current } \\
\text { or last job - } \\
\text { entry wage. } \\
\text { White collar } \\
\text { breadwinner }\end{array}$ & $\begin{array}{c}\text { Current or last } \\
\text { wage - first wage. } \\
\text { Blue collar } \\
\text { breadwinner }\end{array}$ \\
\hline Oldest child & $\begin{array}{c}0.121 * * \\
(0.058)\end{array}$ & $\begin{array}{c}0.144^{* * *} \\
(0.041)\end{array}$ & $\begin{array}{l}-0.038 \\
(0.035)\end{array}$ & $\begin{array}{c}0.004 \\
(0.024)\end{array}$ & $\begin{array}{c}-0.159 * * \\
(0.063)\end{array}$ & $\begin{array}{c}-0.140^{* * *} \\
(0.044)\end{array}$ \\
\hline Number siblings & $\begin{array}{l}-0.028 \\
(0.019)\end{array}$ & $\begin{array}{c}-0.034 * * * \\
(0.011)\end{array}$ & $\begin{array}{c}-0.030^{* * *} \\
(0.011)\end{array}$ & $\begin{array}{c}-0.018^{* *} \\
(0.006)\end{array}$ & $\begin{array}{l}-0.002 \\
(0.021)\end{array}$ & $\begin{array}{c}0.016 \\
(0.012)\end{array}$ \\
\hline Observations & 1,297 & 2,983 & 1,297 & 2,983 & 1,297 & 2,983 \\
\hline R-squared & 0.224 & 0.212 & 0.190 & 0.201 & 0.137 & 0.139 \\
\hline
\end{tabular}


Table A7. Birth order effects on earnings, by prevailing religion in the country

\begin{tabular}{|c|c|c|c|c|c|c|}
\hline & $\begin{array}{c}\text { Entry wage. } \\
\text { Catholic }\end{array}$ & $\begin{array}{c}\text { Entry wage. } \\
\text { Protestant }\end{array}$ & $\begin{array}{l}\text { Wage in } \\
\text { current or last } \\
\text { job. Catholic }\end{array}$ & $\begin{array}{l}\text { Wage in } \\
\text { current or last } \\
\text { job. Protestant }\end{array}$ & $\begin{array}{c}\text { Wage in current } \\
\text { or last job - } \\
\text { entry wage. } \\
\text { Catholic }\end{array}$ & $\begin{array}{l}\text { Current or last wage } \\
\text { - first wage. } \\
\text { Protestant }\end{array}$ \\
\hline Oldest child & $\begin{array}{c}0.139 * * \\
(0.047)\end{array}$ & $\begin{array}{c}0.134 * * \\
(0.060)\end{array}$ & $\begin{array}{l}-0.044 \\
(0.030)\end{array}$ & $\begin{array}{c}0.014 \\
(0.030)\end{array}$ & $\begin{array}{c}-0.183 * * * \\
(0.052)\end{array}$ & $\begin{array}{l}-0.120^{*} \\
(0.062)\end{array}$ \\
\hline Number siblings & $\begin{array}{l}-0.020 \\
(0.013)\end{array}$ & $\begin{array}{c}-0.050 * * * \\
(0.016)\end{array}$ & $\begin{array}{c}-0.019 * * * \\
(0.007)\end{array}$ & $\begin{array}{l}-0.013 \\
(0.009)\end{array}$ & $\begin{array}{c}0.001 \\
(0.014)\end{array}$ & $\begin{array}{c}0.037 * * \\
(0.017)\end{array}$ \\
\hline Observations & 2,320 & 1,318 & 2,320 & 1,318 & 2,320 & 1,318 \\
\hline R-squared & 0.215 & 0.212 & 0.153 & 0.085 & 0.14 & 0.152 \\
\hline
\end{tabular}

Notes: All regressions include dummies for: cohort, country, mother in the house at 10 , father in the house at 10, foster mother in the house at 10 , foster father in the house at 10, grandparents in the house at 10, other relatives in the house at 10, hunger episodes by age 15 , parents smoked, drank or had mental problems, at least one parent died by age 35 , breadwinner occupation at age 10 , lived in rural area at age 10 . Robust standard errors in parentheses. One, two and three stars for statistical significance at the 10, 5 and 1 percent level of confidence. 